\title{
Indian Constitution: The Vision of B. R. Ambedkar
}

\author{
Kamal Kumar \\ Assistant Professor, Department of Political Science, \\ Satyawati College (Day), University of Delhi, Delhi- 110052, India
}

\begin{abstract}
The inception of the Indian Constitution in 1950 was a significant event not only in the political history of India but also in the history of 'social justice' and 'human rights'. At the same time, it has opened up new avenues of human welfare and development in the Indian subcontinent by providing equal rights and privileges to the citizens at large. The Constitution of independent India was meant more than a mere legal manuscript-that likely to structure the norms of governing as well as define the functions of various key institutions and political actors-for the whole society in general and underprivileged sections in particular. The latter were exploited in multiple ways over the centuries owing to the dominant social order of Hindu society, and perhaps this is why, they had a lot of expectations from the newly adopted legal document. The primary aim of the paper is to examine the fact that to what extent the Indian Constitution comprises the vision of B. R. Ambedkar and more specifically, to explore the ways in which the social and political philosophy of Ambedkar have influenced the development of constitution-making in India.
\end{abstract}

Keywords: B. R. Ambedkar, constitutionalism, constitutional provisions, depressed classes, human right, Indian Constitution, social justice.

However good a Constitution may be, it is sure to turn out bad because those who are called to work it, happen to be a bad. However bad a Constitution may be, it may turn out good if those who are called to work it, happen to be a good lot.

\section{Introduction}

India gained the status of 'free' and 'sovereign' nation-state in August 15, 1947 after a long struggle and countless sacrifices. It adopted Constitution on November 26, 1949 which came in enforcement on January 26,1950 . It is often considered as one of the gigantic constitutions in the world which establishes a democratic state. The inception of the Indian Constitution in 1950 was a significant event not only in the political history of India but also in the history of 'social justice' and 'human rights'. At the same time, it has opened up new avenues of human welfare and development in the Indian subcontinent by providing equal rights and privileges to the citizens at large. The Constitution of independent India was meant more than a mere legal manuscriptthat likely to structure the norms of governing, define the functions of various key institutions as well as political actors - for the society as a whole and particularly for the underprivileged sections who were exploited in multiple ways over the centuries especially due to the prevailing dominant social order of Hindu society. The process of constitution-making during the 1940s was thus laden with various sets of expectations and requirements. In fact, it was assumed that the new Constitution would be effective enough to terminate the unending patterns of exploitation based on gender, caste and religion, and bring increasingly sought changes in the deeply hierarchical and unequal social structure so one could live with dignity and possess equal civil rights. It was indeed the first moment in the lives of millions of people, particularly the depressed communities when they were likely to receive an equal treatment and entitlement after the adoption of new Constitution. Gary Jeffrey Jacobson (2010) insists that a nation's Constitution is more than a written legal document as it also entails the fundamental norms and principles of a particular society. Despite the fact that the Constitution of Independent India has borrowed several provisions from the varied Government of India Acts prepared by the Britishers during the colonial period, the Constitution reflects 'Indianess ${ }^{.1}$ But it is not the concern of this paper to traces the various sources which fashioned the constitutional development in India. The central theme of this paper is to examine the fact that to what extent the Indian Constitution comprises the vision of B. R. Ambedkar

\footnotetext{
${ }^{1}$ The word 'Indianess' here denotes the distinctiveness of the Indian context which forced the constitution-makers to evolve some provisions in the constitution to address the particularities of Indian situation.
} 
and more specifically, to explore the ways in which the social and political philosophy of Ambedkar have influenced the development of constitution-making in India.

Dr. Bhimrao Ramji Ambedkar (1891-1956) has been considered as the Chief Architect of the Indian Constitution. The text prepared by Ambedkar offered a wide range of constitutional safeguards and guarantees to all citizens, for instance, socio-economic rights, civil liberties, freedom of religion, the abolition of untouchability and the prohibition of all forms of discrimination among others. He argued for extensive economic and social rights for the depressed classes. In addition to constitutional rights, he eventually won the Assembly's support for introducing a system of reservations of jobs in the civil services, schools and colleges particularly for members of Scheduled Castes and Scheduled Tribes. These measures are popularly known as the 'Policy of Inclusion' that makes endeavours to include the deprived and overlooked classes in the society. However it is very questionable that to what extent these measures have been succeeded in their teleological tasks. In this way, Ambedkar was a valiant fighter for the cause of social justice and social equality, and thus known as the leader, liberator, hero, emancipator, representative of the voices of the socially overlooked classes (Sinha 1993, p. 6). He fought his entire life for the upliftment of the depressed classes. He stated in the Constitution Assembly, "I know today we are divided politically, socially, and economically. We are a group of warring camps, and I may go even to the extent of confessing that I am probably one of the leaders of such a camp" (Mukherjee 2011, p. 209). In this way, he explicitly mentioned his commitment for the depressed sections of society. This paper is concerned with the detailed study of Ambedkar's constitutional vision and its linkages with constitutional developments in India. However, before doing that, it is important to understand the idea of constitutionalism and the conceptualization of Ambedkar on the same in brief.

\section{Constitutionalism and B. R. Ambedkar}

Constitutionalism is different to the Constitution as it is merely not confined to the constitutional text. It talks about past and future of its exercise. Constitutionalism is not all about governance as it also provides contested ideas and practices concerning justice, rights, development and associational autonomy (Schwarz and Ray eds. 2005, p. 540). It is commonly conceived to be the idea that there are legal restraints on the exercise of political authority. It places limits on the state action and conformity with the constitution becomes a guiding principle (Khosla 2013, pp. 5-6). B. R. Ambedkar believed that Constitution is not just a written text but it can be an effective tool to ensure justice and equality to all the sections of society especially to the down-trodden sections of society. He wished to achieve several objectives with the help of constitutional provisions and, in fact, certain provisions can be traced which clearly reflects the influence of his vision on the Indian Constitution - the main task undertaken in this paper. However, it is not necessary that both Constitution and constitutionalism exist together, for instance, the Constitution of India gives great importance to Right to Freedom (Article 19-22). But an individual even does have right to choose their life partner freely which is most evident in the large episodes of honor killings. This fact can be further observed in the various prevailing religion-based, caste-based and lineage-based customs and practices which have been continued to violating the basic rights of an individual in the post-colonial society.

Constitution in India has been framed in such a way in the post-colonial period that it makes endeavour to fulfil those expectations which were created by its people while they were under the yoke of the Britishers. Post-colonialist constitutions therefore have an agenda of development and even stand for the social change. Perhaps, this is why Myron Weiner, a well-known constitutional expert, says that "the Indian Constitution is more than a set of rules guiding behaviour; it is a kind of charter... a set of goals and expectations..." (Revankar 1971, p. 59). It is largely regarded a living thing which has continuously remained in the process of accommodating the necessity of time. Ambedkar, the principal drafter of Constitution, emphatically stated that "in a changing society there must be a constant re-evaluation of old values and the Hindus must realize that if there must be standard to measure the acts of men there must also be readiness to revise these standards" (Ambedkar 1937, p. 80). He thus strongly believed in the fluid concept of constitution.

While presenting the Draft Constitution to the Constituent Assembly in 1948, Ambedkar maintained that "there was nothing to be ashamed of in borrowing because nobody holds any patent rights in the fundamental ideas of a Constitution" (Jacobsohn 2010, p. 170). Perhaps, this is why the creators of Indian Constitution took inspiration from both domestic and foreign sources. Ambedkar had very commitment for the social causes, and he remained committed throughout his life for the upliftment of deprived sections of society. He was known as the pioneer of the idea of 'social justice' in India. He succeeded to arrange certain provisions in the Indian Constitution for ensuring justice to the oppressed sections and creating the 'just society'. In other words, the Indian constitution challenged the dominant conceptualization of justice, equality and welfare in the post-colonial Indian society which disregard a bulk of the populace who in fact needed it most. Also, it made an effort for transforming the hegemonic understanding of social-order in society as well as establishing the ' $j u s t$ ' and 'equal' society. Kalpana Kannabiran (2012) rightly pointed out that the Constitution has prohibited the "practices of discrimination, untouchability and forced labour through the horizontal and vertical application of 
rights" (p.5). It can be argued, the process of constitution-making in India was greatly shaped by the beliefs of Ambedkar. In fact, several provisions can be traced from the Indian Constitution which seeks to realize the vision of Ambedkar-which will be discussed in following section.

\section{B. R. Ambedkar: Shaping the Indian Constitution}

Dr. B. R. Ambedkar, who chaired the Drafting Committee, is notably considered as the 'Father of the Indian Constitution' and played a very pivotal role in the constitution-making. Though when the leadership in the Constituent Assembly selected him to be the Chairman of the Drafting Committee, Ambedkar was very pleasantly amazed at the choice and said that " $i$ came into the Constituent Assembly with no greater aspiration than to safeguard the interest of the Scheduled Castes greatly surprised when the Assembly elected me to the Drafting Committee. I was more than surprised when the Drafting Committee elected me to be its Chairman" (Kashyap 2010, p. 160). This section is divided into two parts. This part presents a detailed analysis of the provisions given in the Indian Constitution which are in a way or other shaped by the social and political philosophy of Ambedkar. The second and last part outlines the views proposed by Ambedkar that could not succeed to find their place in the final draft of the Constitution.

Caste-system in India assigns particular sets of functions and roles even before ones birth, and also provides specific economic, civil, cultural and educational rights to one without a freedom to change. It ignores therefore an individual capabilities, preferences and choices. In this regard, the social order prevail in the Indian society provides no entailments, social and economic rights and freedoms to lower castes, and in contrary, gives manifold opportunities, "privileges and rights to the higher castes, particularly the Brahmins" (Thorat and Kumar eds. 2008, p. 5). Therefore, the fact was much known to the Constituent Assembly that the constitution was going to be introduced in a deeply unequal and discriminatory society. This is probably why its member greatly "debated and drafted the constitution with the explicit purpose of dislodging the status quo" (Kannabiran 2012, p. 38). B. R. Ambedkar, undoubtedly and noticeably, was the man who borne the responsibility to fight against the untouchability and exploitation based on Hindu caste system, and struggled for the untouchables' rights and carved for them a place in the Republican Constitution of India.

Ambedkar vowed to break away untouchability and observed, "If I fail to do away with abominable thraldom and human injustice under which I was born has been groaning, I will put an end to my life with a bullet" (Revankar 1971, p. 35). There are thus several provisions maintained in the Constitution of India that attempt to attain his vision pertaining to the untouchability and caste based discrimination. Ratna G. Revankar (1971, p. 36) held, "the downtrodden sections familiarly known as the 'backward classes' received special attention of the Constitution makers." In fact, the upliftment of these sections has been recognized as an important responsibility of the state and its institution. He presented the various provisions in the Constituent assembly for protecting the interests of the marginalized sections. Articles 15 (4), 16 (4), 19(1) (d) and (e), 29 (2), 275, 330, 335 and 340 incorporated in the Constitution are clearly reflections of his conceptual understanding of social and economic justice. These Articles empower the state to make special provision for securing the interests of socially and educationally backward classes, that is, Scheduled Castes and Scheduled Tribes.

Articles 14, 15, 17 mentioned under the Part III are worth discussing in detail to comprehend the influence of Ambedkar's vision on the Indian Constitution. Article 14 says that "the State shall not deny to any person equality before the laws or the equal protection of the laws within the territory of India." Article 15 prohibits the discrimination on the bases of religion, caste, race sex or palace of birth. Article 17 is the most ground-breaking provision made in the Constitution which abolishes 'untouchability' and outlaws its practices in any form. It is often considered as the provision which has significantly brought the social revolution in the deeply hierarchical and unequal India Indian by criminalizing the practices of untouchability and arranging punishment in accordance with law for those follow it.

Furthermore, Article 23 outlaws forced labour, which has been in general considered as one of the proper mechanisms in establishing the dominant caste rule or feudal regimes particularly in the rural societies which disregard the lower castes. These all provisions are indeed reflections of his great vision in eradicating the evil of untouchability which has been eating the vitals of the society and exposing the country to the threat of disintegration. Besides dignifying the lives of untouchables, it forbids the numerous patterns of discrimination. It has been realized that national freedom gained in 1947 would be ineffective if the fruits of freedom are not equally shared by all in the society. The democratic ethos also emphasizes a footing of equality for all citizens irrespective of their caste affiliations. The aim is to bring about radical social and economic changes, to correct the imbalance in society caused by the caste structure. To quote the learned Ambedkar in his own words, "untouchability is not only a system of unmitigated economic exploitation, but it is also a system of uncontrolled economic exploitation. That is, because there is no independent public opinion to condemn it and there is no impartial machinery of administration and restrain" (Bhatia eds. 1994, p. 7). 
The circumstances necessitating the incorporation of certain articles in the Constitution for backward classes have been further explained by B. R. Ambedkar, "the Indian Constitution must provide safeguards to prevent castes 'with their own interests' from doing mischief to other helpless castes" (Revankar 1971, p. 36). In this way, it can be argued that Ambedkar sought to establish the notion of constitutional morality in an independent India which is defined by, a well-known legal scholar and sociologist, Kannabiran as the "signposts the inauguration of modernity, of a new social order in the subcontinent, which is distinct both from the colonial order and form the social order prior to colonialism" (2012, p. 1). In additional to these constitutional safeguards, the parliament in 1955 has passed the Untouchability (Offences) Act and the same has been comprehensively amended in 1976 for further ensuring justice to low-castes, and later passed the Scheduled Caste and Scheduled Tribe (Prevention of Atrocities) Act, 1989 to prevent atrocities against the members of Scheduled Caste and Scheduled Tribe.

Ambedkar though managed to include certain provisions in the Constitution of India for empowering lower castes, but the fact was much known to him that establishing equal human and civil rights for 'depressed classes' was not sufficient in ensuring justice and welfare to them unless it would be accompanied by the legal provisions and safeguards to uphold those rights in the case of its violation and denial (Thorat and Kumar 2008). He believed that providing rights to all citizens would not enough because the more powerful, the highly privileged higher classes might be able to deny them to lower strata of society. Law therefore should provide remedies against the invasion of fundamental rights. Ambedkar said in the Constituent Assembly that "all of us are aware that rights are nothing unless remedies are provided whereby people can seek to obtain redress when rights are invaded" (Thorat and Kumar eds. 2008, p. 295). Within this background, constitutional remedies have been arranged in the Constitution of India. Article 32 provides the right to all citizens of the country to approach the Supreme Court, if their fundamental rights and constitutional privileges are violated by any state institution or individual. This is perhaps why Ambedkar considered this provision as the very 'soul' of the Constitution and the very heart of it. It is important to note, the Supreme Court later has declared that Article 32 is a part of basic structure of the Constitution.

A close reading of some of his original writings about democracy clearly uncover the fact that B. R. Ambedkar had very optimistic view of democracy. He considered democratic politics as an effective peaceful means to emancipate untouchables from the diverse patterns of exploitation prevailing since the ages as well as to radically alter their way of life. Ambedkar thus defined democracy as a better form of government than all other forms. In this context, he observed, "You have now a way of bringing about change, an improvement in your life conditions. That way is through political actions, through appropriate laws... You can make government provide for you what are now denied - food, clothing, shelter, education... Hence instead of resorting to rosary counting or praters you should now depend on the political path that will bring you liberation..." (Jaffrelot 2005, p. 52). He further explained in the Constituent Assembly on November 19, 1948 that "the reason why we have established in this Constitution a political democracy is because we do not install by any mean whatsoever a perpetual dictatorship of any particular body of people" (Jaffrelot 2005, p. 109). His strong faith in democracy can also be read in his other writings, for instance, once he argued that "we must not only be staunch in our faith in democracy, but we must resolve to see that in whatever we do, we don't help the enemies of democracy to uproot the principles like liberty, equality and fraternity" (Jatava 1965, p. 83). These three principles got noteworthy place in the Preamble itself, which is known as the soul of Indian Constitution. The Preamble says, "Liberty of thought, expression, belief, faith and worship; Equality of status and of opportunity; and to promote among them all, Fraternity assuring the dignity of the individual and the unity of the nation." The principles of liberty, equality and fraternity could not be divorced from each other. It can be argued that the Preamble of the Constitution of India undoubtedly enshrines the philosophy of Ambedkar.

In his writing, Ambedkar had strongly pointed out a 'contradictory' nature of life in the Constituent Assembly, that is, political life possessed a non-discriminatory character whereas socio-economic life, similarly to the past, continued to retain an unfair and unequal nature. More specifically, he claimed that "in political life we will be recognizing the principle of one man one vote and one vote one value. In our social and economic life, we shall, by reason of structure, continue to deny the principle of one man one value" (Khosla 2013, p. 162). Probably, this is why he incorporated the 'Directive Principles of State Policy' enumerated in part IV of the Indian Constitution from Article 36 to 51. This Part is said to promote the ideals of social and economic democracy by guiding the state to make effort for protecting the interests of deprived sections in society. For instance; Article 46 says that "the State shall promote with special care the educational and economic interests of the weaker sections of the people, and in particular, of the Scheduled Castes and Scheduled Tribes, and shall protect them from social injustice and all forms of exploitation." However it should be noted, unlike Fundamental Rights, the Directive Principles are merely a set of instructions to the various states to undertake particular line of actions for the benefits of weaker sections. This fact was also stressed by B. R. Ambedkar, "the Directive Principles are nothing but obligations imposed by the Constitution upon the various Governments in 
the country, though if the Government failed to carry them out, no one could ask for specific preformation" (Ratna 1971, p. 58).

Ambedkar had a staunch faith in the principle of 'secularism' that gives equal respect to all religions. In this respect, he argued that "the state shall not recognize any religion as state religion" (Shivakeri 2004, pp. 149-150). This conceptualization of secularism proposed by Ambedkar was indeed borrowed by the constitutional makers as the Constitution of India gives complete freedom to its citizens to believe in any religion, and to manage their religious activities (Article 25-28). Furthermore, the word 'Secular' is included in the Preamble of Constitution by the Forty-second amendment. Yet, they are certain limits beyond which tolerance cannot go. For instance, the practices of caste and untouchability, economic exploitation and social tyranny, can no longer be permissible. In this way, Ambedkar vision of secularism is of a radical type, and rebel against any religious ill treatment, hatred and discrimination.

Ambedkar, the principal drafter of Constitution, imagined a society where all citizens would possess equal representation within the state institutions. While he failed to pass the provisions related to the 'Separate Electorate' in the Constituent Assembly, he sought to reserve a certain number of seats for untouchables in the State Legislature and the Parliament. In 1920, he had posed the problem of representation faced by untouchable in India: "the right of representation and the right to hold office under the state are the two important rights that make someone a real citizen. But the untouchability of the untouchables puts these rights far beyond their reach... they (the untouchables) can be represented by the untouchables alone" (Thorat and Kumar eds. 2008, p. 337). In a bid to address the concerns of Ambedkar in this context, a certain number of seats have been reserved in the Constitution for the Schedules Castes as well as Scheduled Tribes in the legislature. Part XVI of the Constitution deals with the special provision for backward classes. Further, as per Article 330 and 332 certain numbers of seats are reserved for the Scheduled Castes and Scheduled Tribes in the House of the People and Legislative Assemblies of the States respectively. The reservations of seats for these sections would have not been imagined in the absence of Dr. B R Ambedkar. This is probably why Alistair McMillan (2005) writes that "the retention of electoral reservation for the Scheduled Castes was due to the presence of a powerful spokesperson at the centre of negotiations: Dr Ambedkar... was member of key committees which discussed special representation for the Scheduled Castes" (Bajpai 2011, p. 67). Besides, the reservation has also been made in the central and state appointments in the favour of the Schedules Castes and Scheduled Tribes to ensure their adequate representation in the public services on the one hand, and on the other, to provide an additional platform to make their mark in the mainstream society.

Partha Chatterjee (2007) exhibits a contradictory nature of B. R. Ambedkar in his essay entitled, The Politics of the Governed. He claimed that Ambedkar struggled for arranging the separate political representation of the Dalits, for preferential reservation or affirmative action in their favor in education and government employments, and at the same time, for constructing their distinct culture identity going as far as conversion to another religion - Buddhism. Simultaneously, he also advocated "the interventionist modernizing state and the legal perception of the modern virtues of equal citizenship and secularism... [Seldom has been the tension between the utopian homogeneity and real heterogeneity] played out more dramatically than in the intellectual and political career of B. R. Ambedkar" (Chatterjee 2007, pp. 8-9). Chatterjee hence believes that contradiction is the heart of modern politics, but he fails to underline the pre-requisites of these measures to ensure the justice to the millions of people who have been living on the verge of social slavery and immeasurable exploitation.

Ambedkar held that social union is a necessity to blossom and flourish the democracy in true sense. For that, he suggested the safeguards for the minorities are vital. In democracy, minorities must feel safe. Ambedkar noted that "the suppression and exploitation of minorities in any form is the negation of democracy and humanism. If suppression is not stopped, then democracy degenerates into tyranny" (Jatava 1965, p. 96). Therefore, the provisions have been made to protect the cultural and educational rights of minorities, and to eliminate their fear from the dominance of majority. For example: Article 29 and 30 are proposed to protect the interests of minorities. In this respect, Subhash Kashyap proclaims that the most crucial area which an understanding of Ambedkar's real Constitutional vision has the potential of throwing up a new vistas and fresh perspective is that of minority rights.

Ambedkar gave so much importance to education. He believes that education is essential to moralize and socialize the individuals, especially the backward classes to have a cognizance of self. For him, education facilities should be provided to those who are illiterate and backward, and on the other, to those who want to wipe out the roots of caste system in order to realize the ethos of democracy at the ground level. In this context, Ambedkar observed: "To give education to those who want to keep up the caste system is not to improve the prospect of democracy in India but to put our democracy in India in greater jeopardy" (Ambedkar 1956, p. 31). Article 46 further, as argued earlier, emphasizes his vision which directs the state to take steps to promote the education of the weaker sections-most impotently the Scheduled Castes and Scheduled Tribes. The credit also goes to Ambedkar for the illiteracy programmes and free education up to matriculation guaranteed by the 
different state governments. Later, the 'Right to Education' (Article 21 A) has become the internal part of the Constitution which is earlier part of directive principles as Article 45.

\section{The Unfulfilled Agendas}

Dr. Ambedkar was strongly in favor of 'separate electorate' wherein only an untouchable (Scheduled Caste) voter would have right to cast their vote for untouchable candidate without being influenced from the higher castes. This electorate system was likely to empower untouchables more than any others since here they could choose their own representative from among themselves, thus "constituting themselves into a real political force, whereas the reserved seats left open the possibility of upper caste dominated parties co-opting untouchables, handing out tickets during the elections and electing them, even when this ran contrary to the wishes of local untouchables" (Jaffrelot 2005, p. 54). He succeeded to endow untouchables with a separate electorate at Second Round Table Conference (1931) held in London and this plan famously known as 'Communal Award', however it was later relinquished in the wake of extensive resistance from Gandhi. The demand for separate electorate was again raised in the Memorandum prepared by Ambedkar for the Cabinet Mission Plan, which later submitted to the Constituent Assembly in 1947. In this Memorandum, Ambedkar suggested separate electorate as a "fool-proffer and knave-proof method... to ensure real representation to the Scheduled Castes" (Bajpai 2011, p. 148). Nevertheless, he could not be succeeded once again in arranging separate electorate for untouchables in the new Constitution of India which was finally adopted. In this regard, Sukhadeo Thorat and Narender Kumar (eds. 2008, pp. 36-37) point out, "Referring to an agreement arrived at in the very beginning of the meeting of the Constituent Assembly, Ambedkar mentioned that a give and take formula was adopted so that minorities will not press for Separate Electorates and majority will not oppose reserved seats for the minorities (BAWS 1990, vol. 9: 530-2). It meant that Ambedkar did follow the agreement to avoid any further confusion on the issue and as per situation did not press for Separate Electorates, which he favoured. It shows that though Ambedkar did not really favour reservation over Separate Electorates for representation to the SCs but in the given circumstances he had less option that to accept the arrangement".

Besides fighting for the betterment of untouchables and tribal communities in particular, Ambedkar also sought to bring certain changes in the status of women as well. The fact was quite recognized by him, the situation of women in the Indian society had been more or less similar to, often more deteriorated than, the untouchables from the ages. According to Hindu religious scripts, they are assigned the inferior and subordinate place in the patriarchal Hindu society and the social evils like dowry, child marriage, forced marriage, and subjugation of women among others are extensively practiced. For instance, while observing the status of women in Hindus sacred texts, Jogendra Sinha (1993, p. 63) pointed out, "Women were not given a place of honour by Manu. They were forbidden to study the Vedas... Manu Smriti prescribes that a man of thirty shall marry a maiden of twelve or a man of twenty-fours a girl of eight... Before marriage a girl was required to be under the control of her father or brother. After marriage, she was required to be under the control of her husband".

During the deliberation in the Constituent Assembly, Ambedkar questioned the excessive influence and control of Hindu religion, customs and usages into the private lives of an individual. This too much interference gives one (men) privileges and power to control not just the lives of other (woman), but also offer the justifications to exploit the latter at the vary stages. He strongly stated in the Constituent Assembly, "I personally do not understand why religion should be given this vast, expansive jurisdiction, so as to cover the whole the whole life and to prevent the legislature from encroaching upon that field... We are having this liberty in order to reform our social system, which is full of inequities, discriminations and other things, which conflict with our fundamental rights" (Jaffrelot 2005, p. 115). Hence, he was strongly in the favour to disentangle the private lives from Hindu customs, and strictly limit the role of religion and traditions in one life to the very limited extent. Subsequently, he widely criticized all those members of Constituent Assembly who wished to let the personal laws regulates the individual life. In this context, he also pursued to bring certain changes by replacing the prevailing Hindu laws with western-inspired Civil Code, which famously known as 'The Hindu Code Bill'. The main objectives of this Bill prepared by Ambedkar are worth to highlight here, "Firstly, it seeks to codify the law relating to the rights of property of a deceased Hindu who had died intestate without making a will, both female and male. Secondly, it prescribes a somewhat alerted form of the order of succession among the different heirs to the property of a deceased dying intestate. The next topic it deals with it the law of maintenance, marriage, divorce, adoption, minority and guardianship" (Rodrigues eds. 2007, p 495).

But, unfortunately, Ambedkar could not succeed to make the Hindu Code Bill an integral part of the Indian Constitution owing to the growing and increasingly vocal opposition by the delegates. He just managed to obtain a provision in the Part IV, that is, Article 44, which says that "the State shall endeavour to secure for the citizens a uniform civil code throughout the territory off India." In this respect, Valerian Rodrigues (eds. 2007, p. 471) observes, "Ambedkar's emphasis in his argument on the bill is to reform Hinduism and to create a large enough public space regulated by the rule of law applicable to one and all. He is open to diversity but only 
under the rule of law. The orthodoxy clearly perceived a threat from the Bill, but even those who supported Ambedkar did not do it for the reasons he stressed".

Moreover, in the context of marital relationship, it is imperative to recall article 42 maintained in the initial Draft Constitution, which is submitted to the constituent assembly in 1948 by Ambedkar, says that, "the State shall endeavour to secure that marriage shall be based only on the mutual consent of both sexes and shall be maintained through mutual cooperation, with the equal rights of husband and wife as a basis. The State shall also recognize that motherhood has a special claim on its care and protection" (Kannabiran 2012, p. 369). However this article was later dropped from the final draft of the Constitution, and eventually led Ambedkar to resign from the post of Law Minister in the Nehru Cabinet. ${ }^{2} \mathrm{He}$ held, despite the fact that the Indian society desperately need to reform widely, the Congress and it leadership seemed to maintain the status-quo.

\section{Conclusion}

Dr B. R Ambedkar, the chief draftsman of the Indian Constitution, played a significant part in the process of constitution-making. He raised the voices of those who had been long remained unheard, and had an intense commitment for the social cause and upliftment of deprived and down-trodden sections of society. He explicitly mentioned about swear which he took for the elimination of unjust and inhuman practices from the Hindu society, in the context of untouchables. He was the representative - in the Constituent Assembly — of all downtrodden sections in general and untouchables in particular, and also he proudly proclaimed himself the leader of the latter. He has been considered a pioneer of the notion of 'affirmative actions' and 'inclusive policies' in India and these concepts have emerged out of constant denial of equal rights to specific community in society. He took the responsibility to ensure justice and dignity to low-caste of society. Ambedkar's advocacy of the concept of constitutional morality further emphasized this fact by which he proposed to drastically change the extremely hierarchical and unjust social order whereby every aspect of life was controlled by the higher Hindu caste.

Indian Constitution does incorporate the social and political philosophy of B. R. Ambedkar which is most noticeably evident in the various provisions of the Constitution. The Preamble, Part III, Part IV, and Part XVI among others are determined to establish a "just society by upholding the concepts of liberty, equality, fraternity and safeguarding the unity of the country" (Revankar 1971, p. 58). As argued earlier, Ambedkar gave much priority to the principles of equality, liberty and fraternity. For him, it is necessary to ensure equality in our social and economic life at the earliest possible to solve the problem of Hindu society. And fraternity meant a sense of common brotherhood of all Indians. Ambedkar was aware of the fact that people divided into several thousands of castes could not be a nation thus empathized on social union. These all three principles got significant place in the preamble of Constitution. Part III of the Constitution guarantees a series of fundamental rights to the citizens and some specific provisions have been made to safeguard the special rights and interests of depressed classes. Most importantly, Article 17 is unique in the sense that it has given a blow to the centuryold practice of untouchability. It reflects the spirit of the Constitution - the determination to restore the dignity of the individual and assure fraternity. Untouchability is not only prohibited but it is made punishable by law. Part IV also reflects the conceptualization of Ambedkar on democracy that is to say, a political democracy should be accompanied with the social and police democracy. Part XVI reserves certain number of seats in the legislature in order to provide political representation to the Scheduled Castes and Scheduled Tribes. Indeed, the Constitution of India bears the imprint of his ideas. Probably this is why Christophe Jaffrelot (2005, p. 114) observes that there is no doubt "that the Constitution drew a great deal on the 1935 Government of India Act and the 1928 Nehru Report, Ambedkar influence throughout its preparation was considerable." In the same vein, Rodrigues (2007, p. 471) argues that "Ambedkar drafted several documents which were to shape the constitutional developments in India."

On the other side, it is irony that the practices of exclusion - continual denial of constitutional rights and privileges, equality of opportunity and basic necessities - as well as the vicious exploitation of low-castes in multiple ways in the society has resulted into the large number of cases of dalit atrocities and violence against dalits in the post-colonial India. In this context, Kannabiran (2012, p. 19) highlights some of cases of dalit atrocities taken place after the independence, "In the case of discrimination against dalits, instances of collective violence have occurred at Kilvenmani (44 dalits burnt alive in Tamil Nadu in 1968), Belchi (14 dalits burnt alive in Bihar in 1977), Morichjhanpi (hundreds of dalit refugees massacred by the state in Sunderbans, West Bengal, 1978), Karamchedu (six dalits murdered, there dalit women raped and many more wounded in Andhra Pradesh, 1991), Melavalavu (an elected dalit panchayat leader and five dalits killed in broad daylight in full public view, 1997), Kambalapalli (six dalits burnt alive in Karnataka, 2000), and Jhajjar (five dalits lynched near a police station in Haryana, 2003)".

\footnotetext{
${ }^{2}$ Scholars though argue that were another reasons as well which forced Ambedkar to resign from the Nehru Cabinet, for a detailed analysis see, Christophe Jaffrelot, (2005), Dr. Ambedkar: Analysing and Fighting Caste, New Delhi: Permanent Black, pp. 114-120. 
Even today, such incidents are continued to occur in the large numbers across the entire nation, and often reported in the daily newspapers. The Indian state and its institution have somewhat failed to live up to the ethos of its democratic Constitution in general, and the philosophy and vision of B. R. Ambedkar in particular. The social relations between the caste and sub-caste groups are still governed by higher Hindu castes' hegemonic principles which, in turn, keep excluding the depressed classes-particularly the Scheduled Castes and Scheduled Tribes - sections from achieving the equal status and dignified place in the society. In addition, the rejection of basic necessities like food, water and shelter from the other dominant castes greatly restricts the very basic human right of these communities, that is to say right to live, in the Indian society. Certainly, the Constitution of India comprises the vision of B. R. Ambedkar, which is particularly devoted to the principles of social and economic justice, non-discrimination, liberty, equality and fraternity. However, keeping in mind the growing cases of caste-related violence and dalit atrocities, his vision is yet to be realized in the practice, and it is the task of the governing elite to make efforts to achieve it.

\section{References:}

[1]. Ambedkar, B. R. 1956. Prospects of Democracy in India. New Delhi: Critical Quest.

[2]. Ambedkar, B. R. 1937. Annihilation of Caste, 2nd ed., Bombay: Education Department.

[3]. Bhatia, K. L. eds. 1994. Dr. B R Ambedkar: Social Justice and the Indian Constitution. New Delhi: Deep and Deep Publication.

[4]. Bajpai, Rochana. 2011. Debating Differences: Groups Rights and Liberal Democracy in India. New Delhi: Oxford University Press.

[5]. Chatterjee, Partha. 2007. The Politics of the Governed. 2nd ed. Delhi: Permanent Black.

[6]. Jatava, D R. 1965. The Political Philosophy of B. R. Ambedkar. Agra: Phoenix Publishing Agency.

[7]. Jacobsohn, Gary Jeffrey. 2010. Constitutional Identity. London: Harvard University Press.

[8]. Jaffrelot, Christophe. 2005. Dr. Ambedkar: Analysing and Fighting Caste. New Delhi: Permanent Black.

[9]. Kashyap, Subhash C. 2010. Indian Constitution: Conflict and Controversies. New Delhi: Vitarta Publication.

[10]. Kannabiran, Kalpana. 2012. Tools of Justice: Non-discrimination and the Indian Constitution, New Delhi: Routledge.

[11]. Khosla, Madhav. 2013. The Indian Constitution. New Delhi: Oxford University Press.

[12]. Mohammad, Shabbir. eds. 2008. Ambedkar on Law, Constitution and Social Justice. Jaipur: Rawat Publication.

[13]. Mukherjee, Mithi. 2011. India in the Shadows of Empire: A legal and Political History (1774-1950), 3rd ed., New Delhi: Oxford University Press.

[14]. Revankar, Ratna G. 1971. The Indian Constitution - A Case Study of Backward Class. New Jersey: Fairleigh Dickinson University Press.

[15]. $\quad$ Rodrigues, Valerian. eds. 2007. The Essential Writings of B. R. Ambedkar. New Delhi: Oxford University Press.

[16]. Sinha, Jogendra. 1993. Dr. B. R Ambedkar: A Critical Study. Patna: Vijay Publication.

[17]. Sontakke, Y D. 2004. Thoughts of Dr. Babasaheb Ambedkar. New Delhi: Samyak Prakashan.

[18]. Schwarz, Henry. and Ray, Sangeeta. eds. 2005. A Companion to Postcolonial Studies. Oxford: Blackwell Publishing Ltd.

[19]. Shivakeri, Chandrakant D. 2004. Dr. B. R. Ambedkar's Political Philosophy. New Delhi: Anmol Publication.

[20]. Thorat, Sukhadeo. and Kumar, N. eds. 2008. B. R. Ambedkar: Perspective on Social Exclusion and Inclusive Policies. New Delhi: Oxford University Press. 